\title{
The Making of a Christian Aristocracy: Social and Religious Change in the Western
}

Roman Empire by Michele Renee Salzman, Cambridge, Mass., and London: Harvard University Press, 2002, pp. xiv + 354. ISBN 0-674-00641-0 (Hb).

Mark Humphries (National University of Ireland, Maynooth)

Why did the Roman Empire become Christian? This question has significant ramifications for the whole of western history. Michele Renee Salzman is not, of course, the first to seek to explain this seismic change, but her approach seeks to make good the shortcomings of earlier attempts. She notes (pp. ix-x) the deficiencies of one of the most celebrated efforts, A. D. Nock's Conversion (Oxford, 1933). Nock's investigations were largely concerned with individual experiences, and for the period of late antiquity his main source was Augustine. Salzman highlights some of the difficulties with this approach: how representative is the individual of society (if at all)? And is not Augustine's experience problematic, since he interpreted it in different ways at different points in his life (pp. 11-12)? To compensate, Salzman aims to provide a statistical analysis, albeit of one section of the Empire's population: the senatorial aristocracy. Her investigation depends on a database of 414 aristocrats from the period 284-423 about whom details of religious affiliation are known.

Salzman points out that the senatorial aristocracy of late antiquity was a much broader group than the old senate of Rome. By the end of the fourth century it numbered not hundreds any more, but thousands. The old elite was diluted and diversified by new members drawn from the equestrian order and the provincial nobility who acquired senatorial status as a reward for service of the emperor. However differentiated this new senatorial aristocracy became, one thing united them: a concern for status (pp. 43-61). It is 
this status, understood in Max Weber's terms as "the life fate of men ... determined by a specific, positive or negative, social estimation of honor" (p. 19), that lies at the heart of Salzman's analysis. To put it briefly, aristocratic conversion happened because Christianity became assimilated to the status culture of the imperial elite.

The reality, of course, was more complex. In a series of studies Salzman shows how the dynamics of conversion can be seen to operate in different sections of the senatorial aristocracy. Geographical provenance played an important role. In Rome, Italy, and North Africa, aristocrats were more likely to retain their paganism than were their counterparts in Spain and Gaul. The distinction, Salzman argues, has much to do with the presence of the Christian imperial court in Gaul and its close ties with the career paths of Spanish and Gallic aristocrats. In Italy and North Africa, by contrast, careers often followed traditional trajectories, independent of the imperial court. Those who followed a traditional civic career, particularly at the city of Rome, tended to be mainly pagan until the 370s. Meanwhile senatorial aristocrats, most of them provincials, involved in the imperial bureaucracy, were more likely to be Christian. Such analyses might lead to the expectation that new men raised to senatorial status by Christian emperors were themselves overwhelmingly Christian. Salzman urges caution, however, and argues that any such connection was modest at most. Emperors had to consider a variety of factors when making appointments, such as administrative and military competence, in addition to questions of religious affiliation (pp. 97-106, 128-32). In short, the "top-down" model of Christianity gaining dominance through imperial appointments does not convince Salzman.

Status competition was not limited to male aristocrats, of course. Their womenfolk indulged in it too, although the parameters that defined their activities were very different. The importance of women in understanding not just aristocratic conversion but conversion 
in general is a commonplace in modern scholarship of early Christianity. Salzman contends, however, that the role of women as "critical, active converters" (p. 140) has been overemphasised. While she agrees, on the basis of her database, that the proportion of senatorial women who were Christian was higher than men, she suggests that the surviving evidence might distort the realities. If pagan men are well known from inscriptions, that is because Roman epigraphic habits favoured the commemoration of civic and bureaucratic office holding. By contrast, most senatorial women recorded epigraphically are known only from funerary contexts, particularly Christian cemeteries. Thus the preponderance of Christian women reflects the character of the evidence (pp. 141-3). Salzman is also sceptical of notions that asceticism either provided major new opportunities for aristocratic women or increased their influence: again she notes the distorting nature of the evidence, particularly in treatises that extolled for rhetorical purposes the influence of ascetic women (pp. 167-70).

Throughout her analysis, Salzman argues (against the view recently championed by Timothy Barnes) that aristocratic conversion came late, only gathering momentum some sixty years after Constantine pledged his allegiance to the God of the Christians. This, together with her rejection of the "top-down" model of conversion, suggests that Salzman sees little direct role for the emperor in the process. Indeed, her view of the emperor's influence is more subtle and one that was circumscribed by the emperor's pragmatic concerns of maintaining a good working relationship with the aristocracy. In Salzman's view, the emperor's role was primarily symbolic: as the supreme aristocrat himself, the emperor showed through his personal support and patronage of the Church how Christianity could be integrated with the senatorial elite's status culture (pp. 197-9). Moreover, she argues that the integration of aristocracy and Christianity worked both ways: just aristocrats became more Christian, so Christianity became more aristocratic. Thus the Church became a focus 
for elite patronage; Christians treasured classical literature just as much as scripture (as Julian the Apostate discovered to his chagrin); and aristocratic notions of friendship and nobility endured and bonded with Christian ideals of love and spiritual worth.

Salzman's study offers many insights into this transformation; but how plausible is her interpretation? As noted above, her database comprises 414 aristocrats from a period of 139 years; but this is small, miniscule even, when we consider that there were thousands of aristocrats from the period about whose religious affiliations we know nothing. Moreover, many of Salzman's conclusions are based (as the tables at the end of the volume show very clearly) on even smaller samples. None of this is to say that Salzman's suggestions are invalid; but it must be admitted that their value is limited by the puniness of the data. She herself shows that the evidence distorts in terms of the religious affiliation among women; might it not also in terms of the broader picture? And speaking of the broader picture, how far does Salzman's analysis of aristocratic conversion get us to an understanding of the conversion of other sections of the population? The truth, I suspect, is that Salzman's analysis of a select number of aristocrats is as limited in its own way as Nock's study of individuals. In sum, however much we might want to know why the Roman Empire became Christian, we simply do not have enough evidence to provide a sufficiently nuanced answer. 